\title{
Training PhD students for teaching of engineering disciplines: Study of Russian Universities Experience
}

\author{
Elisabeth LAZAROU \\ University POLITEHNICA of Bucharest, Bucharest, Romania \\ elisabeth.lazarou@upb.ro \\ Natalia VATOLKINA \\ Bauman Moscow State Technical University, Moscow, Russia \\ ocoletta@yandex.ru \\ Maria DASCALU \\ University POLITEHNICA of Bucharest, Bucharest, Romania \\ maria.dascalu@upb.ro \\ Elena SMIRNOVA \\ Bauman Moscow State Technical University, Moscow, Russia \\ evsmirnova@bmstu.ru
}

\begin{abstract}
The paper contains several findings of the study of the Russian universities' system related to pedagogical training of PhD students, which has been carried on in the framework of the ERASMUS+ Capacity Building for HE project EXTEND (\# 586060-EPP-1-2017-1-RO-EPPKA2CBHE-JP) - "Excellence in Engineering Education through Teacher Training and New Pedagogic Approaches in Russia and Tajikistan". The project itself is devoted to the training of new personnel for the engineering universities. The strengths and weaknesses of the Russian system of pedagogical training of young teachers are under discussion in this article.

The Introduction part of the paper describes the Russian system of education, EXTEND project main activities, Project Consortium participants, objective of the analysis of curriculum contents of PhD programs in engineering in Russian universities, including courses and internships on pedagogy, learning outcomes and PhD student's teaching competences and motivation. The methodology part of the paper draws the four stages of the research. The main part of the paper presents the results of the analysis of the $22 \mathrm{PhD}$ programs collected by Russian universities' team. The Discussion part consists of four recommendations on how to enhance the Russian teacher preparation.
\end{abstract}

Keywords: Erasmus+, Education Technology, Competence, Teachers Training, Engineering education, PhD education.

\section{INTRODUCTION}

Russia's Higher Education (HE) system based on the Bologna principles partly includes the following levels of education (Study in Russia - Web-site of Ministry of Science and HE of the Russian Federation, 2019): bachelor's degree (4 years) - ISCED Level 6; master's degree (2 years) - ISCED Level 7; PhD degree (3-4 years) - ISCED Level 9; specialist degree (5-6 years) - ISCED 
Level 8; clinical internship (2 years) - ISCED Level 9. Along with the Bologna's three cycle system a part of traditional Russian system has been kept for the most important and intensive education fields, such as medicine and several fields of engineering. In these fields there are 5 or $6-$ years specialist's degree programs offered, which are equal to ISCED Level 8.

The $\mathrm{PhD}$ degree programs were included in the system of HE degrees only in 2013 according to the Minister of Science and HE Decree \#1259 from November 19, 2013 with modifications in April 2016. Before (between 1925 and 2013), such kind of programs were considered post-graduate education for specialists of highest qualification and were completely research-based. The aim of the $\mathrm{PhD}$ students was to prepare and defend a thesis to obtain the so called Candidate of Science degree, equal to a $\mathrm{PhD}$ degree from the $\mathrm{EU}$ system. If the $\mathrm{PhD}$ student failed to defend thesis, he or she didn't get any document of education. In 2012 new Federal Law \#213-FS "On Education in Russian Federation" was issued and since 2013 the postgraduate education was included in the system of HE Russian Federation (RF).

After the year 2013, the PhD programs were the subjects to Federal State Education Standards (FSES) issued by Ministry of Education and Science of RF. The FSES include requirements to content, duration, learning outcomes and conditions of $\mathrm{PhD}$ programs of certain specialty. To be able to offer a $\mathrm{PhD}$ program, the university must get license and has to pass through the State Accreditation procedure every 5 years. Some characteristics of a $\mathrm{PhD}$ course are presented in the Table 1.

Table 1: Some characteristics of the RF PhD course

\begin{tabular}{|c|c|}
\hline Type of the PhD Course & PhD Course Features \\
\hline Entry requirements & Master's or Specialist Degree \\
\hline Duration of study & $\begin{array}{l}3-4 \text { years (full-time), } \\
4-5 \text { years (part-time) }\end{array}$ \\
\hline Academic qualification certificate & Postgraduate Degree certificate \\
\hline Qualification (Degree) & $\begin{array}{l}\text { Researcher (qualification), research fellow } \\
\text { (qualification), Candidate of Sciences (degree) }\end{array}$ \\
\hline Type of study & $\begin{array}{c}\text { Regular classes according to curriculum, teaching } \\
\text { internship, research }\end{array}$ \\
\hline Form of final state assessment & $\begin{array}{l}\text { Three qualifying examinations for a candidate's } \\
\text { Degree, state examination, dissertation's defense }\end{array}$ \\
\hline $\begin{array}{l}\text { Further career in a scientific and } \\
\text { professional field }\end{array}$ & Doctoral Dissertation Defense \\
\hline Employment & $\begin{array}{c}\text { Research, analytical and scientific work in accordance } \\
\text { with qualification }\end{array}$ \\
\hline
\end{tabular}

The $\mathrm{PhD}$ graduates have the right to be employed as university teacher. As an university teacher, one has to improve one's skills and study at professional training programs with the duration not less than 72 hours (2 ECTS) every three years. It is mandatory to pass through the so-called teacher attestation procedure for prolonging the labor agreement. There is no mention about the possibility to train the PhD students in the field of teaching.

In this context, we carried out a research of the Russian universities' practices of pedagogical training of PhD students. Our activities were done in the framework of the ERASMUS+ Capacity 
Building for HE project EXTEND (\# 586060-EPP-1-2017-1-RO-EPPKA2- CBHE-JP) "Excellence in Engineering Education through Teacher Training and New Pedagogic Approaches in Russia and Tajikistan". The applied methodology was validated and implemented by the eight partner countries (PC) universities from the project.

\section{METHODOLOGY}

The objective of our analysis was to identify the strengths and weaknesses of the system of pedagogical training and retraining of $\mathrm{HE}$ teachers based on the $\mathrm{PhD}$ programs analysis and teachers' retraining in Russian universities. The following tasks had to be solved to achieve the goal: selection and analysis of $\mathrm{PhD}$ programs, selection and analysis of teacher training programs, identification of strengths and areas of improvement of the system of pedagogical training and retraining of teachers of HE.

The methodology of analysis which was applied by us consist of the following stages: 1 . Preparatory stage; 2. Data Collection Stage; 3. Analysis Stage; 4. Discussion and Exploitation Stage (see Figure 1).

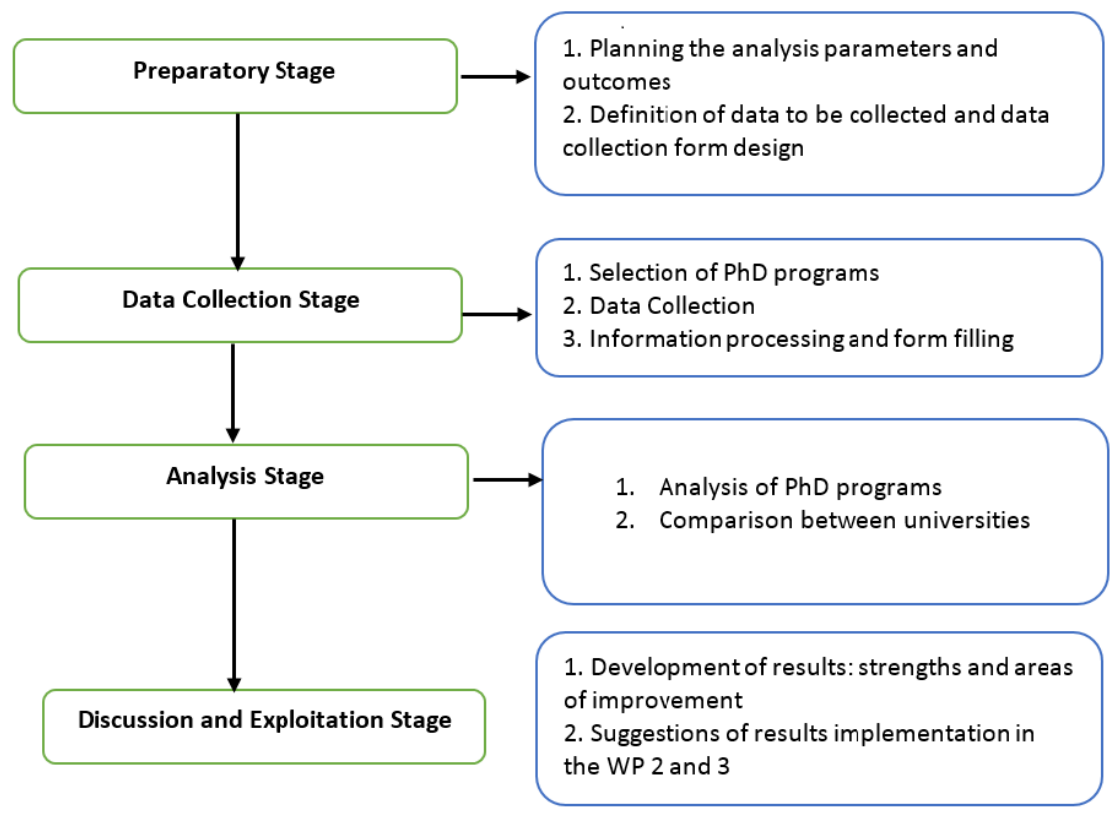

Figure 1: Stages of the Analysis.

\section{Preparatory Stage}

During the preparatory stage, the Project team has decided that each PC university should select several $\mathrm{PhD}$ programs (from 3 to 5) in the field of engineering.

\section{Data Collection Stage}

Data Collection Stage has been performed by the following Russian universities: Moscow State University of Architecture and Civil Engineering (MGSU), Bauman Moscow State Technical University (BMSTU), Nosov Magnitogorsk State Technical University (NMSTU), National Research Mordovia State University (MRSU). In the end, data on $22 \mathrm{PhD}$ programs were collected by the PC universities' teams. (see Table 2).

The current analysis of $\mathrm{PhD}$ programs focuses on two major research directions- engineering and science. The data collection performed by the Russian universities within the project was conducted 
both as a desk and field study. The following documents have been exploited to collect data for the research: federal state education standards on $\mathrm{PhD}$ programs, basic professional educational program (a set of documents describing the contents of the program, learning environment, teaching tools and learning outcomes), curricula, course descriptions, internship descriptions, $\mathrm{PhD}$ department and academic department reports, teacher interviews.

Table 2: Summary of the PhD programs analysed

\begin{tabular}{|c|c|c|}
\hline Russian University & $\begin{array}{c}\text { Number of PhD } \\
\text { Programs }\end{array}$ & $\begin{array}{c}\text { Number of full-time PhD students } \\
\text { (statistics over 3 years) }\end{array}$ \\
\hline MGSU & 5 & 78 \\
\hline BMSTU & 5 & 75 \\
\hline NMSTU & 5 & 32 \\
\hline MRSU & 7 & 63 \\
\hline Total & $\mathbf{2 2}$ & $\mathbf{2 4 8}$ \\
\hline
\end{tabular}

\section{Analysis Stage}

The methods of data analysis were comparison and content analysis. In Russia the Ministry of Science and HE develops and issues obligatory federal state standards, which contain requirements to the structure and learning outcomes of the $\mathrm{PhD}$ programs including competences that graduates should possess. New generation of federal state educational standards are aligned with professional standards and there are references to professional standard of Researcher and professional standard of University teacher. Table 3 shows types of the generalized labour functions and specific labour functions of graduates in accordance with professional standards.

Federal education standards of HE in RF is competence oriented. Each federal education standard of HE includes list of competences graduate should possess upon graduation. Competences are been divided into three groups: generic competences, general professional competences and professional competences.

Generic competences are set for all programs covered by one federal education standard. Generic competences show professional abilities of a person, ensuring successful human activity in a variety of both professional and social sphere (Mishin, 2018). Based on the fact, that the generic competencies are of a non-objective nature, their formation has been carried out within the framework of various forms of organization of the educational process regardless of the specific discipline. They are formed not by "teaching" at the subject-content level, but due to their systematic integration into the educational process through the content, technologies and environmental factors (Rozin, 2018), (Kazakova \& Tarkhanova, 2018).

General professional competences reflect a set of fundamental professional abilities, knowledge and skills of a professional that are invariant for any professional activity in the specific field (Sivitskaya, Smishlyaeva, \& Cmishlkyaev, 2010).

Professional competences are subject-specific competencies bearing the context of a specific professional activity and determine the competitiveness of the graduates (Piskunova \& Erokhina, 2017).

In order to assess and develop the competences acquired by $\mathrm{PhD}$ programs' graduates, the learning outcomes are determined for each competence. Learning outcomes are not presented in the federal education standards, but they are determined by university. It means that the same competence could be under description in different learning outcomes from different universities. 
Table 3: Types of the generalized labour functions and specific labour functions of graduates in accordance with professional standard (Professional standard "Teacher of vocational training, vocational education and additional professional education" - Order of the Ministry of labour and social protection of the Russian Federation, 2019)

\begin{tabular}{|c|c|c|c|}
\hline \multicolumn{2}{|c|}{$\begin{array}{l}\text { Professional } \\
\text { Standard Title }\end{array}$} & $\begin{array}{l}\text { Generalized } \\
\text { labour function }\end{array}$ & Specific Labour Function \\
\hline \multirow{6}{*}{$\begin{array}{l}\text { Teacher } \\
\text { (pedagogical } \\
\text { activity } \\
\text { vocational } \\
\text { education, } \\
\text { additional } \\
\text { professional } \\
\text { education) }\end{array}$} & \multirow{6}{*}{$\mathrm{HE}$, } & \multirow{2}{*}{$\begin{array}{l}\text { Teaching for the } \\
\text { PhD students and } \\
\text { teaching } \\
\text { professional } \\
\text { training courses }\end{array}$} & $\begin{array}{l}\text { Participation in the development of scientific and } \\
\text { methodological support for the implementation of } \\
\text { PhD programs and professional training programs }\end{array}$ \\
\hline & & & $\begin{array}{l}\text { Teaching of courses, disciplines (modules) for the } \\
\text { PhD programs and professional training programs }\end{array}$ \\
\hline & & \multirow{4}{*}{$\begin{array}{l}\text { Teaching for the } \\
\text { bachelor, master } \\
\text { and specialist } \\
\text { degree students and } \\
\text { teaching } \\
\text { professional } \\
\text { training courses }\end{array}$} & $\begin{array}{l}\text { Development of scientific and methodological support } \\
\text { of supervised subjects, courses, disciplines (modules) }\end{array}$ \\
\hline & & & $\begin{array}{l}\text { Teaching of academic subjects, courses, disciplines } \\
\text { (modules) on bachelor's, specialist's, master's and } \\
\text { professional training programs }\end{array}$ \\
\hline & & & $\begin{array}{l}\text { Organization and supervision of research and project } \\
\text { activity of students. Supervision of student's } \\
\text { internships including advisory participation in the } \\
\text { preparation of graduation thesis }\end{array}$ \\
\hline & & & Carrying out career guidance activities for the students \\
\hline
\end{tabular}

According to RF's educational standards, the learning outcomes of each competences are divided into three parts: "Know", "Able To" and "Possess Skills".

Our analysis shows that 21 out of $22 \mathrm{PhD}$ programs of Russian universities include one general professional competence in the field of teaching - "Readiness for teaching on the educational programs of HE".

In MGSU two generic competences are related to teaching activities - "Willingness to participate in the work of Russian and international research teams to solve scientific and educational problems" and "Ability to plan and solve problems of professional and personal development".

In MRSU also two professional competences in teaching are identified in every $\mathrm{PhD}$ program "Readiness for teaching in the specific field" and "Ability to develop scientific and methodological support of educational disciplines in the specific field". It means that teaching is regarded as general professional skill for each $\mathrm{PhD}$ graduate although in some universities the role of the teacher is considered to have more importance than of a $\mathrm{PhD}$ graduate.

The content analysis of learning outcomes shows significant differences between universities in terms of what exactly should know, be able to do and which skills should each $\mathrm{PhD}$ graduate possess to be a university teacher. The generalized learning outcomes are the following:

- Know: the legal framework of HE, basics of psychology and pedagogy of HE, modern educational technology;

- Be able to: choose and apply modern educational technologies, choose relevant material for teaching, apply theoretical and methodological basis in the educational process; conduct teaching activities and develop educational and methodological support;

- Possess: teaching skills, skills of development of educational and methodological support, skills of modeling, application and evaluation of the educational process.

According to (Gülşen, Tosun, \& Tas, 2015) and (Selvi, 2010) the general framework regarding teacher competencies were explained in nine different dimensions as field competencies, research competencies, curriculum competencies, lifelong learning competencies, social-cultural competencies, emotional competencies, communication competencies, information and communication technologies competencies (ICT) and environmental competencies. 
In Russian PhD programs, the focus in teaching competencies is made on the field and curriculum competences along with the research competences which are regarded to be the most important for the $\mathrm{PhD}$ program graduate. Other types of competencies are excluded, and it distorts teacher's competence model, distracts student attention from important soft skills necessary for the effective teaching and self-development. The research and teaching competencies are been disintegrated. At the same time, the contemporary concept of education is "education through research" which identifies the immediate prospects in the sphere of education reforms in the world. Today's Russia is only approaching to this problem consideration at the State level. The political directives made recently are still declarative (Karpov, 2015).

Pedagogical training in the $\mathrm{PhD}$ program includes courses on pedagogy, teaching internship, preparing for the state exam. According to the results of the State final exam, the graduates are awarded the qualification of "Researcher. Teacher-researcher". Each PhD program in Russia includes at least one course on pedagogy and teaching internship (see table 4).

Table 4: Courses and internships on pedagogy in PhD programs of Russian

\begin{tabular}{|c|c|c|}
\hline $\begin{array}{c}\text { Russian } \\
\text { University }\end{array}$ & Courses on Pedagogy & $\begin{array}{r}\text { Universi } \\
\text { Teaching Internship }\end{array}$ \\
\hline MGSU & $\begin{array}{l}\text { Pedagogy and methods of professional } \\
\text { education ( } 2 \text { ECTS) }\end{array}$ & Pedagogical Practice (3 ECTs) \\
\hline BMSTU & $\begin{array}{l}\text { Fundamentals of pedagogy and psychology of } \\
\text { HE (6 ECTS) }\end{array}$ & Pedagogical Practice (18 ECTs) \\
\hline NMSTU & Pedagogy and Psychology of HEI (3 ECTS) & Pedagogical Practice (9 ECTs) \\
\hline MRSU & $\begin{array}{l}\text { IT in research and education (2ECTS) } \\
\text { Pedagogy of HE (2ECTS) }\end{array}$ & Pedagogical Practice (3 ECTs) \\
\hline
\end{tabular}

In Russian Universities each $\mathrm{PhD}$ program has at least one general course on pedagogy with the duration between 2 and 6 ECTS. In addition, in NMSTU the PhD students must acquire a good level of foreign language proficiency to be able to deliver lectures for foreign students and fundamentals of inclusive education to be able to deliver lectures for inclusive students. In MRSU, an additional course is included: "IT in research and education" (2 ECTS). The teaching internship is obligatory and its duration varies between 3 and 18 ECTS. In BMSTU the maximum share of curriculum dedicated to pedagogical training is $10 \%$.

In addition, there are some other courses which contribute to development of related soft skills of the future university teacher, such as: History and Foreign Language (all universities), Communicative and Stylistic features of the Academic language and Writing (BMSTU), Professionally Oriented Translation (NMSTU).

Although the major part of the curriculum is dedicated to professional courses, there are courses on research methodology and research activities, as a consequence of the traditional Soviet approach in which the university teacher was considered a researcher and teaching- an additional activity which needed no special training.

\section{Discussions and Recommendations Stage}

The contextual background allowed identifying the similar structure of the $\mathrm{PhD}$ education in all Russian Universities; most of $\mathrm{PhD}$ programs are been aligned with Bologna system and regarded as HE of 3rd Cycle. The results of study allow us to formulate four recommendations.

Recommendation 1: Develop networking using university teacher's training system to create joint flexible courses and programs.

Analysis revealed that each university has different approaches to teacher training focusing on the specific areas of study. Networking between universities could help to joint efforts and achieve 
synergy effect in development and delivery of fully-fledged training programs for teachers (Fino, Zinchenko, \& Solovyev, 2013). Networking would allow each university to excel in selected area thus improving quality of the whole program. Involvement of foreign partners could provide international dimension to the program.

Recommendation 2: Develop university teacher model of competences with descriptor of learning outcomes for the teacher of engineering disciplines

The competences on teaching used in $\mathrm{PhD}$ programs are standard in Russian universities but at the same are very vague and general. This confuses all stakeholders about the real competences an university teacher should possess. That is why there are significant differences between universities in description of these competences and achieved learning outcomes. On one hand, it allows achieve diversity in teacher training approaches but on the other hand it decreases the compatibility and portability of teaching competences, decreases opportunities for $\mathrm{PhD}$ student mobility and recognition of periods of study in other university, confronts the rights of student for the qualitative education. University teacher model of competences has to be used also for design of teacher enhancement programs. It would help to increase the continuity of teacher training and improve career opportunities.

Recommendation 3: Introduce modular approach to teacher training programs

Each university offer several (some of them offer dozens of) $\mathrm{PhD}$ programs where set of competences could vary as well as duration of the program/course. The modular approach could provide flexibility and scalability of the programs, design tailor-made courses and create network joint programs with partners. Analysis of teaching competences and real contents of the programs/courses allowed identify basic modules to be developed: Project Based Learning (PBL), E-learning and ICT Tools, Foreign Languages for Engineering + Academic Writing, Research Based Learning (PhD Students), Active Learning Strategies, Curriculum Design and Development, Assessment, Design thinking, Communication. The course development needs to be based not only on theoretical background but also on the practical experience of different European and partner university departments through the knowledge exchange practices. For example, BMSTU developed and successfully implemented the project-oriented technology of professional training for aerospace industry (Mayorova , 2011). Another case could be implementation of mind maps and algorithms flowcharts visualization techniques for Electronic Engineering education (Shakhnov, Vlasov, Zinchenko, \& Rezchikova, 2013).

Recommendation 4: Specific courses or modules on "English for specific purposes" for teachers should be designed and offered because in the highly internationalized scientific environments teachers without good command of English language tend to lose professional qualification. Thus, they could gain recognition, publish research, study best practices and help students to adapt their skills to international job market. One of the opportunities to offer such courses is to establish joint or network teacher enhancement programs with partner universities.

\section{CONCLUSIONS}

The current study allowed to identify strength and weaknesses of training $\mathrm{PhD}$ students for teaching in Russian universities based on analysis of $22 \mathrm{PhD}$ programs from 4 Russian universities. The study shows that teaching is one of the major types of professional activities $\mathrm{PhD}$ graduates are trained for. Every $\mathrm{PhD}$ program includes at least one pedagogical competence of the graduate and at least one course in pedagogy and teaching internship. Although the share of the teaching training is relatively low in the total structure of the $\mathrm{PhD}$ program, it shows that pedagogical training is treated as by-product of research activities in $\mathrm{PhD}$ programs. Identified learning outcomes and pedagogic training contents vary significantly between universities which decreases portability and comparability of qualifications, creates obstacles to the $\mathrm{PhD}$ students' mobility. Based on the findings from this study, several recommendations were put forward in the paper. The future research should reveal the educational technologies implemented for pedagogic training in $\mathrm{PhD}$ 
programs in comparison with the observed results of the training. The limitations of the study relate to the relatively small number of programs that were analyzed.

\section{ACKNOWLEDGEMENT}

Authors are grateful to the EU for the financial support of the research work in the framework of the ERASMUS+ Capacity Building for HE project EXTEND (\# 586060-EPP-1-2017-1-RO-EPPKA2CBHE-JP). The name of the project is "Excellence in Engineering Education through Teacher Training and New Pedagogic Approaches in Russia and Tajikistan".

\section{REFERENCES}

Mishin, I. (2018). Critical evaluation of development of list of competences in the federal state education standards of higher education. Vischee obrazovanie $v$ Rossii (Higher education in Russia), 66-75.

(2019, June 4). Retrieved from Study in Russia - Web-site of Ministry of Science and Higher Education of the Russian Federation: https://studyinrussia.ru/en/study-in-russia/info/

Fino, H., Zinchenko, L., \& Solovyev, V. (2013). Challenges for students mobility between European and Russian Universities. 2013 International Conference on Interactive Collaborative Learning (ICL), (pp. 472-479). Kazan.

Gülşen, C., Tosun, U., \& Tas, B. (2015). Opinions of the Secondary Education Teachers on the Classroom. International Conference on New Horizons in Education (INTE), (pp. 95-102). Barcelona.

Karpov , A. (2015). Formation of the Modern Concept of Research Education From New Age to a Knowledge Society. Procedia - Social and Behavioral Sciences. 214, pp. 439-447. Elsevier.

Kazakova, E., \& Tarkhanova, I. (2018). Assessment of generic competences of students oin the process of realization of education programs. Yaroslavskiy pedagogicheskiy vestnik (Pedagogic Tribune of Yaroslavl)(5), 127-135.

Mayorova , V. (2011). Integration of educational and scientific-technological areas during the process of education of aerospace engineers. Acta Astronautica, 69(7-8), 737-743.

Piskunova, K., \& Erokhina, L. (2017). General professional competencies through the prism of a professional standard. Mir nauki (The world of science), 4(5). Retrieved from https://mirnauki.com/PDF/37PDMN417.pdf

Professional standard "Teacher of vocational training, vocational education and additional professional education" - Order of the Ministry of labour and social protection of the Russian Federation. (2019, June 4). Retrieved from Portal of Federal State Educational Standards of Higher Education: http://fgosvo.ru/uploadfiles/profstandart/01.004.pdf

Rozin, A. (2018). Specific features of independent work of students of military universities in the process of training for the professional activity. Mir nauki, kulturi, obrazovania (The world of science, culture, education), 152-153.

Selvi, K. (2010). Teachers' Competencies. International Journal of Philosophy of Culture and Axiology, 167-175. 
Shakhnov, V., Vlasov, A., Zinchenko, L., \& Rezchikova, E. (2013). Visual learning environment in electronic engineering education. International Conference on Interactive Collaborative Learning (ICL), (pp. 379-388). Kazan.

Sivitskaya, L., Smishlyaeva, L., \& Cmishlkyaev, A. (2010). Realization of competence-based approach in higher education: deficiencies of methodic readiness of teachers. Vestnik Tomskogo gosudarstvennogo pedagogicheskogo universiteta (Tribune of Tomsk State Pedagogical University), $102(12), 52-55$. 